\section{Council on Foreign Relations}

Founded 1921. Independent think tank, seeks to foster better understanding of the world and the foreign policy choices facing the USA and other countries. Research by the David Rockefeller Studies Program centres on major geopolitical areas but also covers global health, international institutions and global governance, national security, science and technology and US foreign policy. Sister organization of Chatham House in London.

Address: The Harold Pratt House, 58 East 68th St., New York, NY 10065, USA.

Website: http://www.cfr.org

Board of Directors Chairs: Carla A. Hills; Robert E. Rubin.

President: Richard N. Haass.

\section{Danish Institute for International Studies}

Founded 2002 by the Danish parliament. Independent institution engaged in research in international affairs in order to assess the security and foreign policy situation of Denmark. Research units: defence and security; foreign policy and EU studies; global economy, regulation and development; holocaust and genocide; migration; natural resources and poverty; politics and governance; the Middle East.

Address: Strandgade 56, 1401 Copenhagen, Denmark. Website: http://www.diis.dk

Director: Nanna Hvidt.

\section{European Council on Foreign Relations}

Founded 2007. Pan-European think tank that conducts European foreign policy research and promotes a more integrated European foreign policy in support of shared European interests and values. Main programmes: Russia and wider Europe; China; democracy, human rights and the rule of law.

Address: 35 Old Queen St., London SW1H 9JA, UK.

Website: http://www.ecfr.eu

President: Asger Aamund.

\section{European Policy Centre}

Independent, non-profit think tank committed to making European integration work. Aims to promote a balanced dialogue between the different constituencies of its membership, spanning all aspects of economic and social life. Programmes: EU integration and citizenship; Europe's political economy; Europe in the world.

Address: Résidence Palace, 155 rue de la Loi, B-1040 Brussels, Belgium.

Website: http://www.epc.eu

Chairman: Peter Sutherland.

\section{European Union Institute for Security Studies}

Founded 2001. Autonomous EU agency operating under the Common Foreign and Security Policy (CFSP). Aims to find a common security culture for the EU, develop and project the CFSP and enrich Europe's strategic debate. Research areas: EU foreign policy; security and defence policy; disarmament; global governance.

Address: 43 avenue du Président Wilson, 75775 Paris, Cedex 16, France.

Website: http://www.iss.europa.eu

Director: Álvaro de Vasconcelos.
Foundation for Social Studies and Analysis (Fundación para el Análisis y los Estudios Sociales)

Founded 1989. Liberal private non-profit organization that seeks to reinforce the values of Western freedom, democracy and humanism and to create, promote and spread ideas that are based on political, intellectual and economic freedom. Research themes: political thought; Spanish constitutional matters; rule of law; international policy; fight against terror; economy; public policies.

Address: Calle María de Molina 40, 6th floor, 28006 Madrid,

Spain.

Website: http://www.fundacionfaes.org

Secretary-General: Jaime García-Legaz.

\section{Fraser Institute}

Founded 1974. Independent non-partisan research and educational organization that aims to measure, study and communicate the impact of competitive markets and government interventions on the welfare of individuals. Research covers taxation, government spending, health care, school performance and trade.

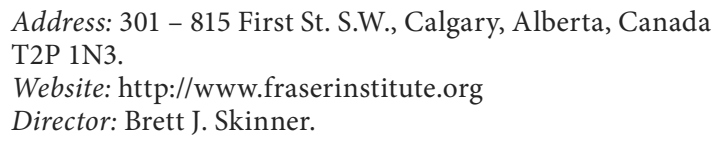

\section{Freedom House}

Founded 1941. Independent watchdog organization that supports democratic change internationally, monitors freedom, and advocates for democracy and human rights. Programmes support human rights and democracy advocates in their efforts to promote open government, defend human rights, strengthen civil society and facilitate the free flow of information and ideas.

Address: 1301 Connecticut Ave., NW, Floor 6, Washington, D.C., 20036, USA.

Website: http://www.freedomhouse.org

Executive Director: David J. Kramer.

\section{French Institute of International Relations (IFRI)}

Founded 1979. The Institut Français des Relations Internationales is an independent research and debate institution dedicated to international affairs. Research centres on geographic regions as well as economy; energy; Franco-German relations; health/ environment; migration; identities and citizenship; security and defence; space; and sport.

Address: 27 rue de la Procession, 75740 Paris, Cedex 15,

France.

Website: http://www.ifri.org

Secretary-General: Valérie Genin.

\section{Fundação Getulio Vargas}

Founded 1944. Higher education establishment dedicated to social sciences research to develop the socio-economic position of Brazil. Research covers business, citizenship, education, finance, justice, health, history, law, macro and microeconomics, politics, pollution, poverty and unemployment, sustainable development and welfare.

Address: Praia de Botafogo 190, Rio de Janeiro, 22250-900

Brazil.

Website: http://www.fgv.br

President: Carlos Ivan Simonsen Leal. 